\title{
Preparation of Ceria-zirconia Mixed Oxides with Improved Thermal Stability for Three-way Catalysts by a Modified Co-precipitation Method
}

\author{
WU Qing-Feng ${ }^{1}$, CUI Ya-Juan ${ }^{2}$, ZHANG Hai-Long ${ }^{3}$, ZHOU Yi ${ }^{1}$, LAN Li ${ }^{1}$, WANG Jian-Li ${ }^{2}$, CHEN Yao-Qiang ${ }^{1,2}$ \\ (1. College of Chemistry, Sichuan University, Chengdu 610064, China; 2. Key Laboratory of Green Chemistry \& Technology of \\ Ministry of Education, College of Chemistry, Sichuan University, Chengdu 610064, China; 3. College of Chemical Engineering, Si- \\ chuan University, Chengdu 610064, China)
}

\begin{abstract}
A series of ceria-zirconia mixed oxides (CZ- $x ; x=0,20,40$ and 80 ) with Ce/Zr molar ratio of 3/2 were synthesized by co-precipitation method. In order to improve the thermal stability of ceria-zirconia mixed oxides, we extended the time for the primary grain to grow up by a modified synthesis reactor. The resulting samples were characterized by X-ray diffraction (XRD), $\mathrm{N}_{2}$ adsorption-desorption, and transmission electron microscopy (TEM). The results revealed that bigger grain could be obtained by extending time for the primary grain to grow up, which was propitious to enhance the textural properties and structural properties of the materials. Thus, the thermal stability of the materials was improved. In this study, the materials were applied in the field of Pd-only three way catalysts (TWCs). The catalysts exhibited excellent catalytic performance and thermostability, showing better prospect in application.
\end{abstract}

Key words: ceria-zirconia composites; primary grain; co-precipitation; thermostability

The emissions of pollutants from automotive exhausts have caused the air pollution around our living cities $^{[1-2]}$. Currently, the most effective way for the gasoline engine cars is the equipment of three-way catalytic converters which can convert the primary pollutants of carbon monoxide (CO), hydrocarbons ( $\mathrm{HCs}$ ) and nitrogen oxides $\left(\mathrm{NO}_{x}\right)$ into relatively environmentally friendly products of $\mathrm{CO}_{2}, \mathrm{H}_{2} \mathrm{O}$ and $\mathrm{N}_{2}$ under actual conditions ${ }^{[3-5]}$. Ceria-zirconia mixed oxides have been widely applied for automotive three-way catalysts (TWCs) because of stronger redox and oxygen storage abilities ${ }^{[6]}$. However, higher exhaust temperatures $\left(>1000^{\circ} \mathrm{C}\right)$ must demand a better thermal stability of TWCs in applications ${ }^{[1,7]}$.

Many efforts have been spent to improve the thermal stability of ceria-zirconia mixed oxides ${ }^{[8-11]}$. It has been found that many factors could affect the thermal stability of the oxides ${ }^{[3,8,12]}$, wherein the pore structure of materials is the main one ${ }^{[7]}$. Broadly speaking, larger pores could prevent the sintering of the materials. And larger pores are usually piled up by larger crystalline grains. Therefore, the aim of this study is to improve thermal stability of ceria-zirconia mixed oxides by a modified co-precipitation method, which can increase the crystalline size of materials.

\section{Experimental}

\subsection{The modified co-precipitation method}

A modified co-precipitation method was designed (Fig. 1) and used for the synthesis of $\mathrm{CeO}_{2}-\mathrm{ZrO}_{2}$ mixed oxides.

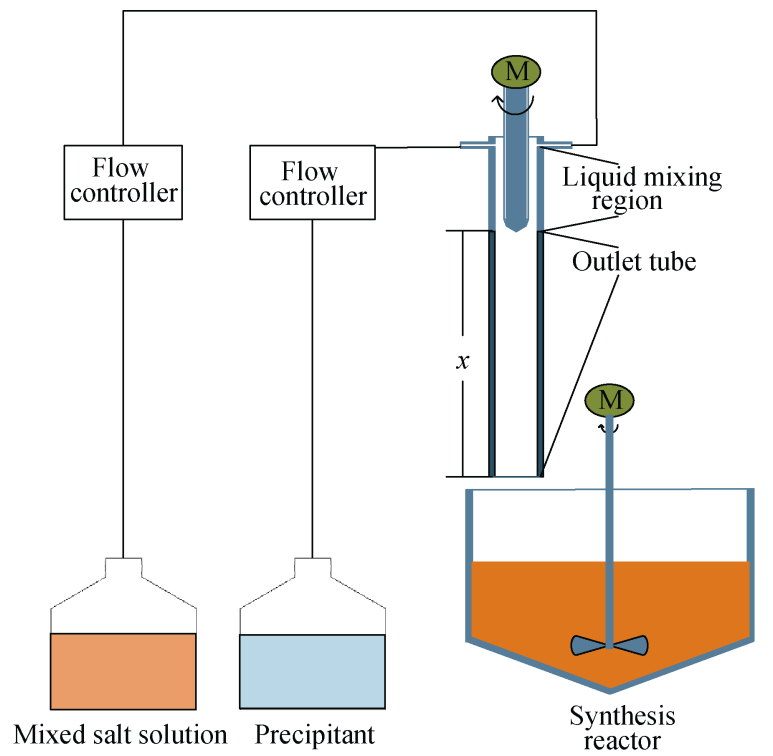

Fig. 1 Schematic diagram for the modified co-precipitation method 
The synthesis reactor consisted of a liquid mixing region and an outlet tube on the upper and a slurry collector under the outlet tube. When the mixed salt solution and the precipitant were pumped into the liquid mixing region, the two fluids were mixed together with stirring and the crystal nucleus would start to form. Then the mixed fluids with crystal nucleus flowed down along the inner wall of the outlet tube and were collected by the slurry collector. Meanwhile, the grains initiated to grow. When the length of the outlet tube increased, the time for grains to grow up would become longer.

\subsection{Synthesis of $\mathrm{CeO}_{2}-\mathrm{ZrO}_{2}$ mixed oxides}

$\mathrm{CeO}_{2}-\mathrm{ZrO}_{2}$ materials with $\mathrm{Ce} / \mathrm{Zr}$ molar ratio of $3 / 2$ were prepared by the modified co-precipitation method. Firstly, $\mathrm{Ce}\left(\mathrm{NO}_{3}\right)_{3} \cdot 6 \mathrm{H}_{2} \mathrm{O}$ and $\mathrm{ZrO}\left(\mathrm{CO}_{3}\right)$ precursors were dissolved in distilled water and nitric acid solution, respectively, and then mixed. Finally, the precipitates were obtained by dropping ammonia. During this process, the length of the outlet tube was adjusted to $0,20,40$ and $80 \mathrm{~cm}$, respectively, to gradually extend the time for grains growing. Afterwards, the obtained precipitates were filtered and dried at $120^{\circ} \mathrm{C}$ for $12 \mathrm{~h}$. The dried precipitate powders were marked as CZ-x-d ( $x=0,20,40$ and 80). A portion of the precipitate powders were calcined at $600^{\circ} \mathrm{C}$ for $3 \mathrm{~h}$ in air to obtain the fresh samples, which were labeled as $\mathrm{CZ}-\mathrm{x}-\mathrm{f}$, and the aged samples were obtained by thermal treating at $1000^{\circ} \mathrm{C}$ in air for $5 \mathrm{~h}$, which were assigned as CZ- $x$-a.

\subsection{Preparation of three-way catalysts (TWCs)}

Further considering the applications of the obtained CZ-80 in TWCs, the corresponding Pd/CZ- $x(x=0,80)$ catalysts with $1.5 \mathrm{wt} \%$ Pd were prepared by impregnation method to study the effects of the modified co-precipitation method. The coating amount onto honeycomb cordierites (Corning, USA, 400 cells/inch ${ }^{2}, 2.5 \mathrm{~cm}^{3}$ ) was $160 \mathrm{~g} / \mathrm{L}$. The obtained samples were calcined at $600^{\circ} \mathrm{C}$ in air for $3 \mathrm{~h}$ to obtain the fresh catalysts, which were marked as Pd/CZ- $x$-f. The aged catalysts were gained by aging at $1000^{\circ} \mathrm{C}$ in air for $5 \mathrm{~h}$, which were labeled as $\mathrm{Pd} / \mathrm{CZ}-\mathrm{x}$-a.

\subsection{Evaluation of catalytic performance}

The catalytic performance of TWCs was evaluated in a multiple fixed-bed continuum flow micro-reactor with the inlet gas mixture simulated as the automobile exhaust gases, including $\mathrm{CO}(0.6 \%), \mathrm{C}_{3} \mathrm{H}_{8}(0.06 \%)$, $\mathrm{NO}(0.06 \%)$, $\mathrm{CO}_{2}(12 \%), \mathrm{H}_{2} \mathrm{O}(10 \%), \mathrm{O}_{2}$ (adjustable) and the balance gas $\mathrm{N}_{2}$. The gas space velocity was $40,000 \mathrm{~h}^{-1}$. The concentrations of the effluent $\mathrm{C}_{3} \mathrm{H}_{8}, \mathrm{CO}$, and $\mathrm{NO}$ were analyzed by a FGA-4100 five-component analyzer (Foshan
Analysis Instrument Co., Ltd., China). The excess air ratio $(\lambda)$ is defined as $\lambda=\left\{2\left[\mathrm{O}_{2}\right]+[\mathrm{NO}]\right\} /\left\{10\left[\mathrm{C}_{3} \mathrm{H}_{8}\right]+[\mathrm{CO}]\right\}$, and controlled at $\lambda=1$ during the catalytic activity measurements.

\subsection{Characterization}

The X-ray diffraction (XRD) patterns of all samples were determined by a Rigaku DX-2500 diffractometer equipped with $\mathrm{Cu} \mathrm{K} \alpha(\lambda=0.15406 \mathrm{~nm})$. The X-ray tube was operated at $40 \mathrm{kV}$ and $30 \mathrm{~mA}$. All samples were scanned with a step of $0.06^{\circ}$ in the range of $20^{\circ} \leqslant 2 \theta \leqslant 70^{\circ}$.

The textural properties of the ceria-zirconia mixed oxides were analyzed by $\mathrm{N}_{2}$ adsorption/desorption at $77 \mathrm{~K}$ by the Quantachrome S-30 surface area and pore size analyzer. The specific surface area and the pore size distribution were calculated by the Brunauer-Emmett- Teller (BET) and Barret-Joyner-Halenda (BJH) methods, respectively.

Transmission electron microscopy (TEM) images of the samples were taken using a Tecnai $\mathrm{G}^{2}$ F20 S-TWIN TEM (FEI Company, USA, $200 \mathrm{kV}$ accelerating voltage). The mean particle sizes of the $\mathrm{CeO}_{2}-\mathrm{ZrO}_{2}$ mixed oxides were calculated from TEM images by averaging 30 points of the oxide particles.

\section{Results and discussions}

\subsection{X-ray diffraction analysis (XRD)}

The XRD patterns of all the samples are displayed in Fig. 2. The average crystallite sizes and the lattice parameters are also exhibited in Table 1. Firstly, all the precipitates exhibit the characteristic peaks of cubic fluorite-like $\mathrm{CeO}_{2}$ phase. This suggests that only few $\mathrm{Zr}$ atoms have inserted into the $\mathrm{CeO}_{2}$ lattice. In the ceria-zirconia system, insertion of $\mathrm{Zr}^{4+}$ with smaller ionic radius $(0.084 \mathrm{~nm})$ compared to the 8-coordinated $\mathrm{Ce}^{4+}$ ion $(0.097 \mathrm{~nm})$ into the $\mathrm{CeO}_{2}$ lattice could decrease the cell volume and create more structural defects ${ }^{[13-15]}$. Thus, smaller lattice constant indicates that more $\mathrm{Zr}$ atoms have inserted into the $\mathrm{CeO}_{2}$ lattice. The lattice constants of CZ-0-d, CZ-20-d, CZ-40-d and CZ-80-d were calculated to be $0.5421,0.5422,0.5380$ and $0.5380 \mathrm{~nm}$, respectively. This suggests that much more $\mathrm{Zr}$ atoms have inserted into the lattice of CZ-40-d and CZ-80-d. Moreover, the grain size of the samples follows a decreasing tendency of CZ-80-d > CZ-40-d > CZ-20-d $>$ CZ-0-d. It is obvious that the primary grain size increases with the length of the outlet tube. Therefore, a conclusion can be drawn that longer outlet tube contributes to the growth of crystallites in the initial precipitate particles. 


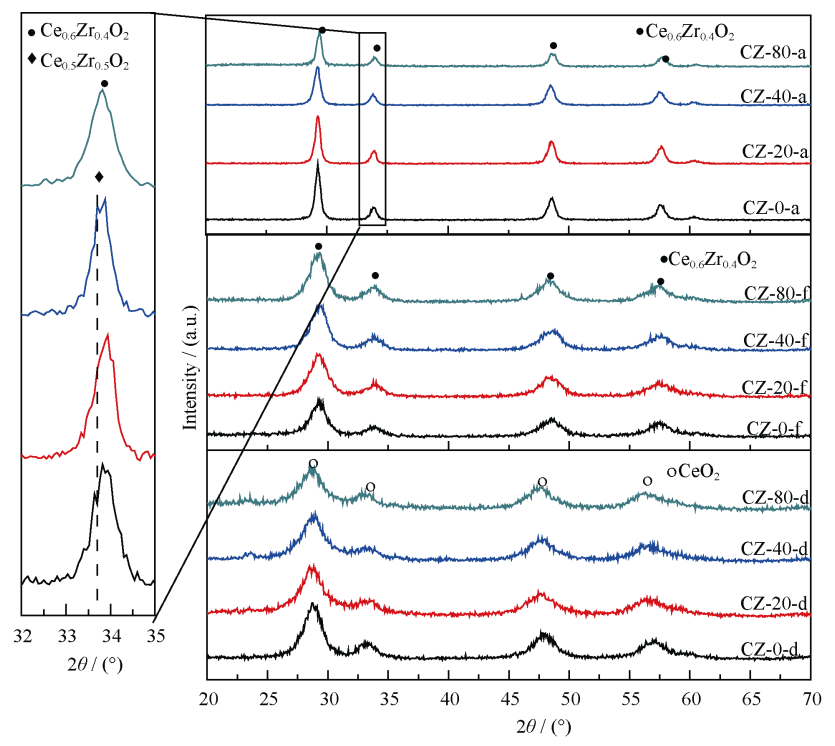

Fig. 2 XRD patterns of the precipitates, fresh samples and aged samples

Table 1 The crystalline phases, lattice parameters and crystallite sizes of the precipitates, fresh samples and aged samples

\begin{tabular}{cccc}
\hline Samples & Phase composition & $\begin{array}{c}\text { Lattice pa- } \\
\text { rameter/nm }\end{array}$ & $\begin{array}{c}\text { Crystallite } \\
\text { size/nm }\end{array}$ \\
\hline CZ-0-d & Cubic & 0.5421 & 3.7 \\
CZ-20-d & Cubic & 0.5422 & 3.8 \\
CZ-40-d & Cubic & 0.5380 & 4.0 \\
CZ-80-d & Cubic & 0.5380 & 4.3 \\
CZ-0-f & Cubic & 0.5274 & 4.8 \\
CZ-20-f & Cubic & 0.5284 & 4.8 \\
CZ-40-f & Cubic & 0.5271 & 5.0 \\
CZ-80-f & Cubic & 0.5291 & 4.9 \\
CZ-0-a & Cubic + tetragonal & $0.5258^{\mathrm{a}}$ & 21.2 \\
CZ-20-a & Cubic + tetragonal & $0.5261^{\mathrm{a}}$ & 19.3 \\
CZ-40-a & Cubic + tetragonal & $0.5286^{\mathrm{a}}$ & 17.2 \\
CZ-80-a & Cubic & 0.5292 & 14.5 \\
\hline
\end{tabular}

${ }^{\mathrm{a}}$ Crystallite size based on the cubic phase.

After thermal treatment at $600^{\circ} \mathrm{C}$ for $3 \mathrm{~h}$, all the diffraction peaks become narrower and sharper and all the $2 \theta$ values shift to higher angles. This indicates that much more $\mathrm{Zr}$ atoms have inserted into the $\mathrm{CeO}_{2}$ lattice to form solid solutions, and the symmetrical peaks indicate that all the fresh samples are single-phase solid solutions, which is characteristic of cubic $\mathrm{Ce}_{0.6} \mathrm{Zr}_{0.4} \mathrm{O}_{2}$ phase ${ }^{[12]}$. After aging at $1000^{\circ} \mathrm{C}$ for $5 \mathrm{~h}$, all the diffraction peaks become even narrower and sharper (Fig. 2), indicating that all the aged samples undergo a rapid crystallite growth process (Table 1$)^{[16]}$. Apparent peak splitting is observed in CZ-0-a, CZ-20-a and CZ-40-a, which indicates that phase segregation has occurred in these samples. However, no peak splitting is observed in CZ-80-a which still maintains the single cubic $\mathrm{Ce}_{0.6} \mathrm{Zr}_{0.4} \mathrm{O}_{2}$ phase, suggesting that $\mathrm{CZ}-80$ own superior structural property. Generally, single-phase $\mathrm{CeO}_{2}-\mathrm{ZrO}_{2}$ solid solutions usually own better textural property, thermal stability and redox behaviors with respect to phase-segregated nonhomogeneous ones ${ }^{[3,17]}$. Except for the phase variation, the grain sizes of CZ-0-a, CZ-20-a, CZ-40-a and CZ-80-a have increased greatly, which are 21.2, 19.317 .2 and $14.5 \mathrm{~nm}$, respectively. For fine particles, due to the rapid grain growth during thermal aging, pores are agglomerated by moving the grain boundaries ${ }^{[18]}$. The grain size of CZ-80-a is apparently smaller than those of others, which indicates that material CZ- 80 is more stable than others. However, from the point of view of grain sintering, material CZ-80 owns the biggest primary grain size $(4.3 \mathrm{~nm})$ which turns out to be the smallest $(14.5 \mathrm{~nm})$ after themal aging at $1000^{\circ} \mathrm{C}$. For comparison, material CZ-0 has the smallest primary grain size $(3.7 \mathrm{~nm})$ which is biggest after thermal aging $(21.2 \mathrm{~nm})$. This suggests that less primary grains have sintered together during the high temperature aging, and material CZ-80 exhibits superior structural property and thermal stability.

\subsection{Textural characterization}

The textural properties of the samples were characterized by BET method. The results, including specific surface areas, pore volumes and average pore radii, are summarized in Table 2. As shown in Table 2, the surface areas and pore volumes of the fresh samples are all above $110 \mathrm{~m}^{2} / \mathrm{g}$ and $0.25 \mathrm{~cm}^{3} / \mathrm{g}$, respectively, indicating that all fresh samples own good textural property. After calcined at $1000^{\circ} \mathrm{C}$ for $5 \mathrm{~h}$, the specific surface areas of all the samples obviously reduce by severe aggregation of the nano-particles, and their accumulative pore volumes also remarkably decrease. Compared with other samples, however, CZ-80-a maintains higher surface area of $29 \mathrm{~m}^{2} / \mathrm{g}$ and larger pore volume of $0.13 \mathrm{~cm}^{3} / \mathrm{g}$ which are $13 \mathrm{~m}^{2} / \mathrm{g}$ and $0.05 \mathrm{~cm}^{3} / \mathrm{g}$ higher than those of $\mathrm{CZ}-0-\mathrm{a}$, respectively. These results indicate that CZ- 80 has the best textural property with good thermal stability.

In order to study the pore structure and sintering

Table 2 Textural properties of fresh and aged samples

\begin{tabular}{cccc}
\hline Samples & $\begin{array}{c}\text { Specific sur- } \\
\text { face } /\left(\mathrm{m}^{2} \cdot \mathrm{g}^{-1}\right)\end{array}$ & $\begin{array}{c}\text { Pore vol- } \\
\mathrm{ume} /\left(\mathrm{cm}^{3} \cdot \mathrm{g}^{-1}\right)\end{array}$ & $\begin{array}{c}\text { Average pore } \\
\text { radius } / \mathrm{nm}\end{array}$ \\
\hline $\mathrm{CZ}-0-\mathrm{f}$ & 118 & 0.25 & 4.2 \\
$\mathrm{CZ}-20-\mathrm{f}$ & 137 & 0.27 & 3.9 \\
$\mathrm{CZ}-40-\mathrm{f}$ & 120 & 0.27 & 4.5 \\
$\mathrm{CZ}-80-\mathrm{f}$ & 129 & 0.30 & 4.6 \\
$\mathrm{CZ}-0-\mathrm{a}$ & 16 & 0.08 & 10.7 \\
$\mathrm{CZ}-20-\mathrm{a}$ & 15 & 0.07 & 9.3 \\
$\mathrm{CZ}-40-\mathrm{a}$ & 22 & 0.11 & 10.2 \\
$\mathrm{CZ}-80-\mathrm{a}$ & 29 & 0.13 & 9.0 \\
\hline
\end{tabular}


behavior of the samples, the corresponding $\mathrm{BJH}$ pore size distribution curves of the fresh and aged samples are depicted in Fig. 3 and Fig. 4. For the fresh samples, the detailed statistical data (Table 3 ) calculated from Fig. 3 show great differences among these samples. Firstly, the proportions of the pores distributed below $3 \mathrm{~nm}$ decrease in the order of CZ-0-f $\approx \mathrm{CZ}-20-\mathrm{f}>\mathrm{CZ}-40$ - $\mathrm{f}>\mathrm{CZ}-80$-f. The proportions of the pores distributed between $3-6 \mathrm{~nm}$ for CZ-0-f, CZ-20-f, CZ-40-f and CZ-80-f are 32.7\%, 31.1\%, $40.6 \%$ and $47.8 \%$, respectively. And the proportions of the pores distributed above $6 \mathrm{~nm}$ for all the fresh samples are almost the same. After aging at $1000^{\circ} \mathrm{C}$ for $5 \mathrm{~h}$, the pore size distributions of the samples have changed drastically (Fig. 4 and Table 4). From the statistical data listed in Table 4, the proportions of the pores distributed between 6-16 nm for CZ-0-a, CZ-20-a, CZ-40-a and CZ-80-a are $43.7 \%, 49.6 \%, 63.0 \%$ and $77.5 \%$, respectively. For CZ-80-a, the proportions of the pores distributed below $6 \mathrm{~nm}$ and above $16 \mathrm{~nm}$ are both very small. This indicates that the pore size distribution of CZ-80-a is more concentrated than those of others. Combined with its bigger pore volume, this indicates that the pore structure of CZ-80 is more stable than those of others, and this result could also account for its superior textural property. Furthermore, the above proportions of the pores distributed between 3-6 nm

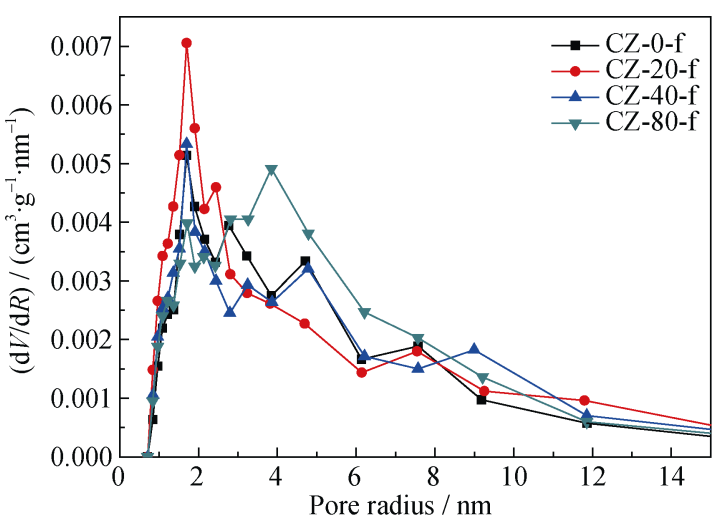

Fig. 3 Pore size distributions of fresh samples

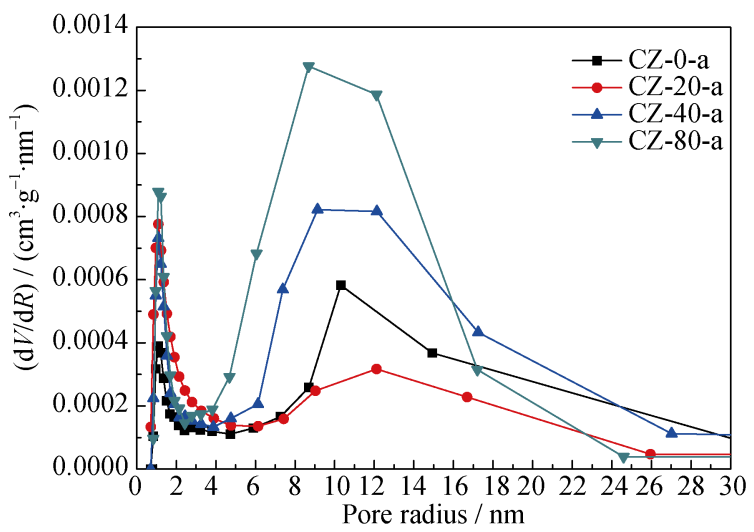

Fig. 4 Pore size distribution of aged samples
Table 3 Statistical data of the proportion of pore radius for pore size distribution of fresh samples

\begin{tabular}{cccc}
\hline Samples & Below 3 nm & $\begin{array}{c}\text { Between 3 nm } \\
\text { and 6 nm }\end{array}$ & Above 6 nm \\
\hline CZ-0-f & $37.6 \%$ & $32.7 \%$ & $29.7 \%$ \\
CZ-20-f & $39.0 \%$ & $31.1 \%$ & $29.9 \%$ \\
CZ-40-f & $30.1 \%$ & $40.6 \%$ & $29.3 \%$ \\
CZ-80-f & $22.8 \%$ & $47.8 \%$ & $29.4 \%$ \\
\hline
\end{tabular}

Table 4 Statistical data of the proportion of pore radius for pore size distribution of aged samples

\begin{tabular}{cccc}
\hline Samples & Below 6 nm & $\begin{array}{c}\text { Between 6 nm } \\
\text { and 16 nm }\end{array}$ & Above 16 nm \\
\hline CZ-0-a & $10.0 \%$ & $43.7 \%$ & $46.3 \%$ \\
CZ-20-a & $26.3 \%$ & $49.6 \%$ & $24.1 \%$ \\
CZ-40-a & $14.3 \%$ & $63.0 \%$ & $22.7 \%$ \\
CZ-80-a & $12.9 \%$ & $77.5 \%$ & $9.6 \%$ \\
\hline
\end{tabular}

in fresh samples might be related to the different sintering behavior of the pore structure in different samples. These results make us speculate that the bigger average pore radius with higher percentage of large pores is key parameter for the materials with high thermal stability.

\subsection{Transmission electron microscopy (TEM)}

The morphologies of CZ-0 and CZ-80 were investigated by TEM, and the results are shown in Fig. 5. The average grain sizes of CZ-0 and CZ-80 are calculated with the help of Digital Micrograph, and the results are shown in Table 5. From Fig. 5, it can be observed that both precipitates are composed of many sphere-like nanoclusters with similar packing modes. The average grain sizes of CZ-80-d and CZ-0-d are $4.3 \mathrm{~nm}$ and $3.3 \mathrm{~nm}$, respectively.
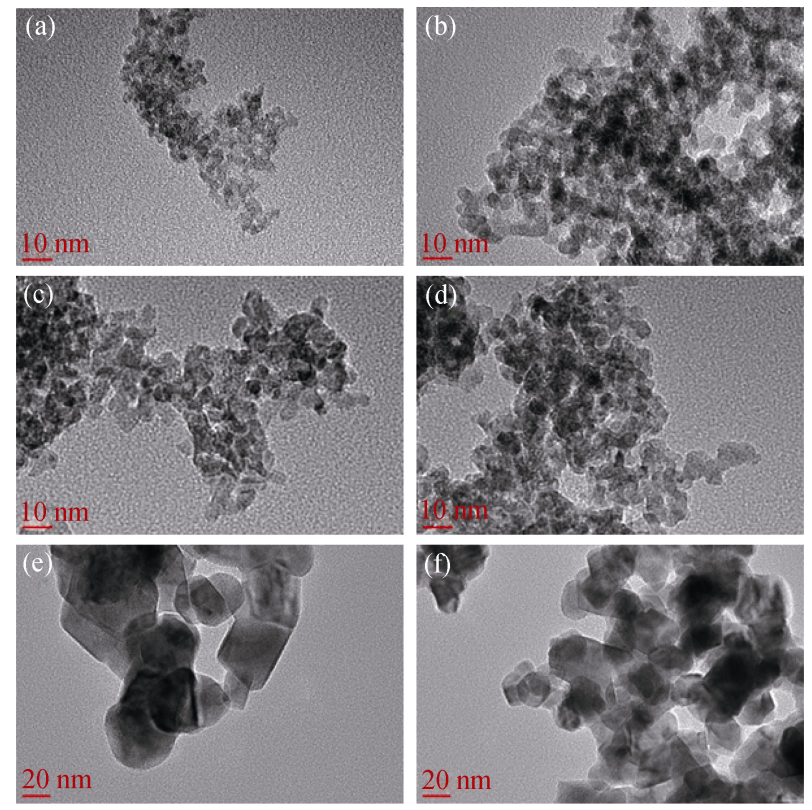

Fig. 5 TEM images of samples

(a) CZ-0-d; (b) CZ-80-d; (c) CZ-0-f; (d) CZ-80-f; (e) $\mathrm{CZ}-0$-a; (f) CZ-80-a 
Table 5 The average grain sizes of $\mathrm{CZ}-0$ and $\mathrm{CZ}-80$ calculated from TEM results

\begin{tabular}{cccc}
\hline Samples & Precipitates/nm & $\begin{array}{c}\text { Fresh sam- } \\
\text { ples/nm }\end{array}$ & $\begin{array}{c}\text { Aged sam- } \\
\text { ples } / \mathrm{nm}\end{array}$ \\
\hline CZ-0 & 3.3 & 4.8 & 25.6 \\
CZ-80 & 4.3 & 5.1 & 16.3 \\
\hline
\end{tabular}

The significantly larger grain size of CZ-80-d is quite in accordance with the above XRD results and confirms that the grain size increases with the length of the outlet tube. After thermal treatment at $600^{\circ} \mathrm{C}$, the difference of the grain size between CZ-80-f and CZ-0-f declines, but the grain size of $\mathrm{CZ}-80-\mathrm{f}$ is still larger than that of CZ-0-f. After aging at $1000^{\circ} \mathrm{C}$, the average grain sizes of CZ-80-d and CZ-0-d increase to $16.3 \mathrm{~nm}$ and $25.6 \mathrm{~nm}$, respectively. From the point of view of sintering, the great divergence in the growth of the grain size from the initial precipitate particles to the $1000^{\circ} \mathrm{C}$ thermal aged ones in these two samples might be related to the length of the outlet tube. A possible mechanism of grain growth from initial precipitate particles can be proposed as Fig. 6. Contacting with the textural properties and $\mathrm{XRD}$ results, it can be speculated that the excellent anti-sintering performance of CZ-80 is attributed to the formation of larger grains at the primary stage of precipitation, and the generation of bigger pores through accumulation of the grains, which are helpful for improving the thermal ability. This might be attributed to that there is more time for the grains to grow up at the primary stage of precipitation when the length of the outlet tube increases to $80 \mathrm{~cm}$. So it can be concluded that the bigger the initial grain size is, the better the thermal stability is.

\subsection{Catalytic performance}

The results of the catalytic activity evaluation performed over the fresh and aged catalysts are summarizedin Table 6. For the fresh catalysts $\mathrm{Pd} / \mathrm{CZ}-0-\mathrm{f}$ and $\mathrm{Pd} / \mathrm{CZ}-80-\mathrm{f}$, the complete transformation temperatures $\left(T_{90}\right)$ of $\mathrm{C}_{3} \mathrm{H}_{8}, \mathrm{NO}$ and $\mathrm{CO}$ are almost the same. This would be attributed to their high surface areas which have provided enough spaces for the dispersion of the metal particles. After aging, both catalysts are deactivated to a certain extent. The $T_{90}$ of $\mathrm{C}_{3} \mathrm{H}_{8}, \mathrm{NO}$ and COfor $\mathrm{Pd} / \mathrm{CZ}-80$-a are $400^{\circ} \mathrm{C}, 290^{\circ} \mathrm{C}$ and $272^{\circ} \mathrm{C}$, respectively,

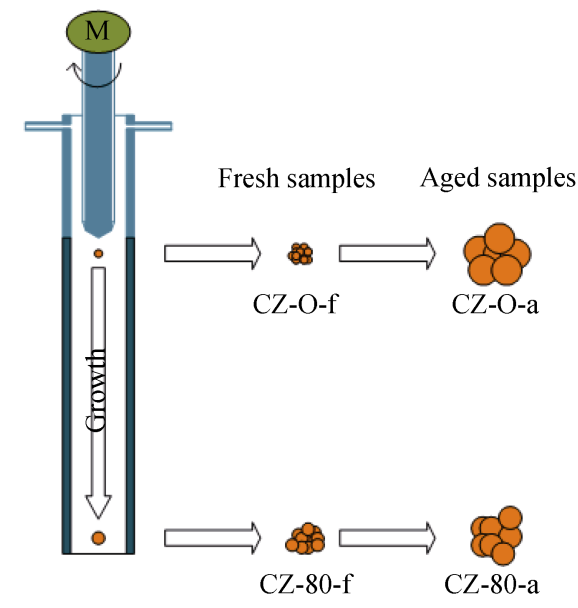

Fig. 6 Schematic diagram of growing and sintering process of grains

while the values for $\mathrm{Pd} / \mathrm{CZ}-0$-a are $420^{\circ} \mathrm{C}, 298^{\circ} \mathrm{C}$ and $293{ }^{\circ} \mathrm{C}$, respectively. For $\mathrm{Pd} / \mathrm{CZ}-80-\mathrm{a}$, the $T_{90}$ of $\mathrm{C}_{3} \mathrm{H}_{8}$, $\mathrm{NO}$ and $\mathrm{CO}$ are $20^{\circ} \mathrm{C}, 8^{\circ} \mathrm{C}$ and $21^{\circ} \mathrm{C}$ lower than those of $\mathrm{Pd} / \mathrm{CZ}-0-\mathrm{a}$. As reported in the previous studies ${ }^{[3,19]}$, the sintering of the support would result in the encapsulation of metal particles and further cause the deactivation of the catalyst. Therefore, the better catalytic performance observed for $\mathrm{Pd} / \mathrm{CZ}-80$-a is due to the superior structural property and excellent thermal stability of corresponding support material CZ-80.

\section{Conclusions}

In this study, a series of ceria-zirconia mixed oxides were prepared by a modified co-precipitation method with the synthesis reactor equipped with an outlet tube with different lengths. Based on the results and discussion pre sented above, the following conclusions can be drawn:

1) The primary grain size increases with the length of the outlet tube.

2) Sample CZ-80 exhibits superior structural property and thermal stability.

3) Sample CZ-80 has the best textural property with good thermal stability. After aging at $1000^{\circ} \mathrm{C}$ for $5 \mathrm{~h}$ in air, the specific surface area and pore volume of $\mathrm{CZ}-80$ are maintained at $29 \mathrm{~m}^{2} / \mathrm{g}$ and $0.13 \mathrm{~cm}^{3} / \mathrm{g}$, respectively.

Table 6 Light-off temperatures $\left(T_{50}\right)$ and complete conversion temperatures $\left(T_{90}\right)$ for $\mathrm{C}_{3} \mathrm{H}_{8}$, NO and CO over fresh and aged catalysts.

\begin{tabular}{|c|c|c|c|c|c|c|}
\hline \multirow{2}{*}{ Catalysts } & \multicolumn{3}{|c|}{$T_{50} /{ }^{\circ} \mathrm{C}$} & \multicolumn{3}{|c|}{$T_{90} /{ }^{\circ} \mathrm{C}$} \\
\hline & $\mathrm{C}_{3} \mathrm{H}_{8}$ & NO & $\mathrm{CO}$ & $\mathrm{C}_{3} \mathrm{H}_{8}$ & NO & $\mathrm{CO}$ \\
\hline $\mathrm{Pd} / \mathrm{CZ}-0-\mathrm{f}$ & 273 & 180 & 163 & 325 & 230 & 219 \\
\hline $\mathrm{Pd} / \mathrm{CZ}-0-\mathrm{a}$ & 358 & 266 & 249 & 420 & 298 & 293 \\
\hline $\mathrm{Pd} / \mathrm{CZ}-80-\mathrm{f}$ & 270 & 180 & 167 & 326 & 228 & 228 \\
\hline $\mathrm{Pd} / \mathrm{CZ}-80-\mathrm{a}$ & 332 & 258 & 241 & 400 & 290 & 272 \\
\hline
\end{tabular}


4) Higher thermal stability of the catalytic performance of $\mathrm{Pd} / \mathrm{CZ}-80$ is also obtained. This has further confirmed that CZ-80 has better prospect in application.

\section{References:}

[1] KAŠPAR J, FORNASIERO P, HICKEY N. Automotive catalytic converters: current status and some perspectives. Catal. Today, 2003, 77(4): 419-449.

[2] MATSUMOTO S. Recent advances in automobile exhaust catalysts. Catal. Today, 2004, 90(3/4): 183-190.

[3] KAŠPAR J, FORNASIERO P. Nanostructured materials for advanced automotive de-pollution catalysts. Solid State Chem., 2003, 171(1/2): 19-29.

[4] FARRAUTO R J, HECK R M. Catalytic converters: state of the art and perspectives. Catal. Today, 1999, 51(3/4): 351-360.

[5] HECK R M, FARRAUTO R J. Automobile exhaust catalysts. Appl. Catal. A: Gen., 2001, 221(1/2): 443-457.

[6] KAŠPAR J, FORNASIERO P, GRAZIANI M. Use of $\mathrm{CeO}_{2}$-based oxides in the three-way catalysis. Catal. Today, 1999, 50(2): 285-298.

[7] MONTE R D, KAŠPAR J. Heterogeneous environmental catalysis-a gentle art: $\mathrm{CeO}_{2}-\mathrm{ZrO}_{2}$ mixed oxides as a case history. Catal. Today, 2005, 100(1/2): 27-35.

[8] SHIGAPOV A N, GRAHAM G W, MCCABE R W, et al. The preparation of high-surface area, thermally-stable, metal-oxide

[9] catalysts and supports by a cellulose templating approach. Appl. Catal. A: Gen., 2001, 210(1/2): 287-300.

[10] BUMAJDAD A, ZAKI M I, EASTOE J, et al. Microemulsionbased synthesis of $\mathrm{CeO}_{2}$ powders with high surface area and hightemperature stabilities. Langmuir, 2004, 20(25): 11223-11233.

[11] FUENTES R O, BAKER R T. Synthesis of nanocrystalline$\mathrm{CeO}_{2}-\mathrm{ZrO}_{2}$ solid solutions by a citrate complexation route: a thermochemical and structural study. J. Phys. Chem. C, 2009, 113(3): 914-924.
[12] NAKATANI T, OKAMOTO H, OTA R. Preparation of $\mathrm{CeO}_{2}-\mathrm{ZrO}_{2}$ mixed oxide powders by the coprecipitation method for the purification catalysts of automotive emission. J. Sol-Gel Science and Technology, 2003, 26(1): 859-863.

[13] KAŠPAR J, FORNASIERO P, BALDUCCI G, et al. Effect of $\mathrm{ZrO}_{2}$ content on textural and structural properties of $\mathrm{CeO}_{2}-\mathrm{ZrO}_{2}$ solid solutions made by citrate complexation route. Inorg. Chim. Acta, 2003, 349(5): 217-226.

[14] TROVARELLI A, ZAMAR F, LLORCA J, et al. Nanophase fluorite-structured $\mathrm{CeO}_{2}-\mathrm{ZrO}_{2}$ catalysts prepared by high-energy mechanical milling. J. Catal., 1997, 169(2): 490-502.

[15] BOARO M, VICARIO M, LEITENBURG C D, et al. The use of temperature-programmed and dynamic/transient methods in catalysis: characterization of ceria-based. Catal. Today, 2003, 77(4): 407-417.

[16] FORNISIERO P, MONTE R D, RAO G R, et al. Rh-loaded $\mathrm{CeO}_{2}-\mathrm{ZrO}_{2}$ solid solutions as highly efficient oxygen exchangers: dependence of the reduction behavior and the oxygen storage capacity on the structural properties. J. Catal., 1995, 151(1): 168-177.

[17] WENG X, PERSTON B, WANG X Z, et al. Synthesis and characterization of doped nano-sized ceria-zirconia solid solutions. Appl. Catal. B: Environ., 2009, 90(3/4): 405-415.

[18] SUN Y, SERMON P A. Surface reactivity and bulk properties of $\mathrm{ZrO}_{2}$ Part 2-Importance of homogeneity in the stabilisation of high surface area $\mathrm{CeO}_{2}-\mathrm{ZrO}_{2}$ aerogels. J. Mater. Chem, 1996, 6(6): $1025-1029$

[19] MONTE R D, KAŠPAR J, BRADSHAW H, et al. A rationale for the development of thermally stable nanostructured $\mathrm{CeO}_{2}-\mathrm{ZrO}_{2}$ - containing mixed oxides. J. Rare Earths, 2008, 26(2): 136-140.

[20] ZHOU Y, LAN L, GONG M, et al. Modification of the thermal stability of doped $\mathrm{CeO}_{2}-\mathrm{ZrO}_{2}$ mixed oxides with the addition of triethylamine and its application as a Pd-only three-way catalyst. $J$. Mater. Sci., 2016, 51(9): 4283-4295.

\title{
改进共沉淀法以提高三效催化剂中铈锆复合氧化物的热稳定性
}

\author{
伍青峰 ${ }^{1}$, 崔亚娟 ${ }^{2}$, 张海龙 ${ }^{3}$, 周 怡 ${ }^{1}$, 兰 丽 ${ }^{1}$, 王健礼 ${ }^{2}$, 陈耀强 ${ }^{1,2}$ \\ (四川大学 1. 化学学院; 2. 化学学院, 绿色化学与技术教育部重点实验室; 3. 化工学院, 成都 610064)
}

\begin{abstract}
摘 要: 采用共沉淀法制备了铈锆材料(铈锆比为 3/2)。通过改进反应器装置(图 1), 延长了初始晶粒生长的时间, 提 高了铈铅材料的热稳定性。采用 X 射线衍射(XRD)、氮气吸脱附和透射电镜(TEM)对制备的材料进行了表征。结果 表明, 延长初始晶粒生长的时间可以得到较大尺寸的晶粒, 这有利于提高材料的织构和结构性能, 从而提高热稳 定性。本研究将该材料应用于单 Pd 三效催化剂，表现出了优异的活性和热稳定性，具有良好的应用前景。

关 键 词: 铈锆材料; 初始晶粒; 共沉淀法; 热稳定性

中图分类号: TQ174 文献标识码: A
\end{abstract}

